Board of Governors of the Federal Reserve System

International Finance Discussion Papers

Number 1069

December 2012

\title{
Sovereign Credit Risk, Banks' Government Support, and Bank Stock Returns around the World
}

\author{
Ricardo Correa \\ Kuan-Hui Lee \\ Horacio Sapriza \\ Gustavo Suarez
}

NOTE: International Finance Discussion Papers are preliminary materials circulated to stimulate discussion and critical comment. References to International Finance Discussion Papers (other than an acknowledgment that the writer has had access to unpublished material) should be cleared with the author or authors. Recent IFDPs are available on the Web at www.federalreserve.gov/pubs/ifdp/. This paper can be downloaded without charge from the Social Science Research Network electronic library at www.ssrn.com. 


\title{
Sovereign Credit Risk, Banks' Government Support, and Bank Stock Returns around the World
}

\author{
RICARDO CORREA \\ Federal Reserve Board \\ HORACIO SAPRIZA \\ Federal Reserve Board
}

\author{
KUAN-HUI LEE \\ Seoul National University Business School \\ GUSTAVO SUAREZ ${ }^{*}$ \\ Federal Reserve Board
}

December 20, 2012

\begin{abstract}
We explore the joint effect of expected government support to banks and changes in sovereign credit ratings on bank stock returns using data for banks in 37 countries between 1995 and 2011. We find that sovereign credit rating downgrades have a large negative effect on bank stock returns for those banks that are expected to receive stronger support from their governments. This result is stronger for banks in advanced economies where governments are better-positioned to provide that support. Our results suggest that stock market investors perceive sovereigns and domestic banks as markedly interconnected, partly through government guarantees.
\end{abstract}

Keywords: sovereign bond, credit rating, bank stock returns, government guarantees JEL Classification: G21, G24, H63, G14

\footnotetext{
* The views in this paper are solely the responsibility of the authors and should not be interpreted as reflecting the views of the Board of Governors of the Federal Reserve System or of any other person associated with the Federal Reserve System. For very useful feedback that greatly improved the paper, we very grateful to Jakob de Haan, an anonymous referee, and Reint Gropp (the discussant at the Post-Crisis Banking Conference organized by the Dutch Central Bank, the European Banking Center, and the University of Kansas School of Business). For useful comments, we also thank Chris Karlsten, Stijn Claessens, Eric Engstrom, Juan Carlos Hatchondo, Jean Helwege, David Mayes, Dror Parnes, and seminar and conference participants at the International Monetary Fund, the Federal Reserve Board, the Post-Crisis Banking Conference in Tilburg, the Federal Reserve Bank of Richmond, and the 2012 meetings of the Midwest Finance Association, the Financial Management Association, the International Banking, Economics, and Finance Association, and the Southern Finance Association. We also thank Hal Baseman and Sarah Hirsch for excellent research assistance.

Ricardo Correa is a senior economist at the Federal Reserve Board (Ricardo.Correa@frb.gov), Kuan-Hui Lee is an assistant professor of finance at the Seoul National University Business School (kuanlee@snu.ac.kr), Horacio Sapriza is an economist at the Federal Reserve Board (Horacio.Sapriza@frb.gov), and Gustavo Suarez is a senior economist at the Federal Reserve Board (Gustavo.A.Suarez@frb.gov).
} 


\section{INTRODUCTION}

The ongoing global financial crisis has strongly highlighted that investors believe that banks are closely connected with their governments. Both governments and banks are typically very dependent on domestic economic activity, which affects tax revenues and the demand for financial services. In addition, banks tend to hold significant volumes of domestic sovereign debt on their balance sheets, which implies that the creditworthiness of the government directly impacts the asset quality of the banking sector. Moreover, and perhaps the subject of the most intense political debate in recent years, many investors expect governments to support troubled domestic banks, as widespread bank failures may adversely affect economic activity.

In this paper, we study the connection between banks and governments by focusing on bank stock returns after sovereign rating changes, relatively discrete events that signal changes in the financial conditions of governments. More importantly, we exploit cross-sectional variation in the stock market response of banks to sovereign rating changes to better understand the transmission mechanism that operates from the fiscal situation of the government to the financial health of the banking sector. In other words, we are interested in understanding why stock market investors believe that banks are connected with their governments. Studying stock price reactions to discrete events like sovereign rating downgrades allows us to focus on a tight window during which fewer spurious factors are likely to explain the connection between the health of the banking sector and the fiscal situation of the government. 
To study the stock market reaction to sovereign rating changes, we first identify 314 sovereign rating changes that affected the debt issued by governments in 37 developed and emerging economies from 1995 to 2011 using ratings data from Standard \& Poor's Ratings Services (henceforth, S\&P). We next collect data from Datastream/Worldscope and Moody’s Investors Service (henceforth, Moody’s) for 259 banks in our sample of countries. Our empirical approach consists on exploiting crosssectional differences across stock price reactions to sovereign rating agencies, based on different bank characteristics. Most prominently, we exploit measures of expected government support to individual banks. We construct our baseline measure of government support using ratings data from Moody's. In particular, Moody’s assigns bank deposit ratings for banks as standalone entities and also assigns bank deposit ratings that take into account possible external support to the banks (including explicit or implicit deposit insurance). Our baseline measure of expected government support reflects the difference between the credit rating that embeds external support and the standalone rating (Schich and Lindh 2012). ${ }^{1}$ To our knowledge, this is one of the first applications of this measure in empirical studies.

Our main results are as follows:first, we find that sovereign rating changes have a strong effect on the stock returns of banks that are more likely to receive government support. This effect is concentrated on sovereign rating downgrades and generally is not statistically significant for sovereign rating upgrades. These results are robust to using alternative measures of government support that capture the probability of government support (e.g., Gropp, Hakenes, and Schnabel 2011) and different event windows.

\footnotetext{
${ }^{1}$ In Section 3, we show that this ratings-based measure of government support is intuitively correlated with variables that capture the ability and willingness of governments to bail out individual financial institutions.
} 
Second, we find that the negative effect of sovereign downgrades on bank stock returns for banks expected to receive government support is likely not explained by the effect of the sovereign downgrade on the entire economy. In particular, we find that banks expected to receive government support have lower stock returns after sovereign rating downgrades, even when we compare stock market performance against domestic equity price indexes, which are likely to capture the overall negative effects of downgrades on domestic economic activity. This result suggests that the negative effects of a sovereign rating downgrade are disproportionately felt by banks that investors perceive as likely to receive more government support when in trouble.

Third, we find that the negative stock market performance after sovereign downgrades of banks expected to receive government support is likely not explained by holdings of domestic government debt. Unfortunately, bank-level holdings of domestic government debt are generally not publicly available. However, sovereign debt holdings for European banks were disclosed as part of stress tests conducted in 2011 with the objective of restoring market confidence. For the subsample of European banks for which we observe sovereign debt holdings, we find that banks expected to receive government support exhibit lower stock returns after a sovereign downgrade, even after controlling for domestic government debt holdings on bank balance sheets. In addition, we find that the stock prices of banks with high sovereign debt holdings tend to be slightly positive around sovereign debt upgrades, but the economic magnitude of this effect is small relative to the negative effect of sovereign rating downgrades on banks that market participants expect to receive government support. Our results highlight that expected government support is a very important channel in explaining the stock market 
reaction of banks to sovereign downgrades, although not to the exclusion of other channels.

In addition, we find that the negative effect of sovereign rating downgrades on stock returns of banks that are likely to be supported by their governments is nonlinear in a number of interesting ways. In particular, larger downgrades (of at least two notches) tend to have significantly more pronounced effects than smaller downgrades (of less than two notches). Moreover, our baseline results are stronger for advanced economies, suggesting that investors perceive that stock returns of banks are closely connected to the health of their government, as long as the government is in a credible position to support the banking sector, perhaps because governments in developed countries have more ample borrowing capacities in international debt markets.

This paper is closely connected with two strands of the literature that study the link between governments and the stock market performance of firms in the private sector. The first branch of the literature related to our paper focuses on the impact of sovereign rating changes on all firms in the economy or on stock indexes (e.g., Kaminsky and Schmukler 2002, Brooks et al. 2004, Martell 2005, and Lee, Sapriza, and Wu 2010). To our knowledge, our paper is the first study to focus specifically on the effect of sovereign rating changes on banks and to exploit variation across banks in their stock market reaction to sovereign rating news to study separate transmission channels that connect banks with sovereign credit risk.

The second branch of the literature closely related to our paper analyses the effect of government fiscal troubles on bank performance. In particular, Demirgüç-Kunt and 
Huizinga (2010) document that measures of equity market valuation tend to be lower for banks that are larger relative to their domestic economies, particularly in countries where governments are running large public deficits. We view our findings as complementary with those of Demirgüç-Kunt and Huizinga (2010). First, we study the link between governments and banks using relatively discrete events, such as sovereign rating changes, which provide distinct information about the financial situation of the government. The tighter windows around these events are likely to exclude many confounding factors that may also explain an empirical relationship between the financial condition of the government and bank market valuations and that are more likely to be present in crosscountry regressions. In addition, the link between government support and bank market valuations in Demirgüç-Kunt and Huizinga (2010) is focused on one dimension of government support, namely that governments tend to support systemically important institutions, as measured by the size of the institution relative to the domestic economy. However, governments may consider many other factors when deciding whether to support a specific financial institution (e.g., the interconnectedness of the institution or its type of customers). These additional factors are included in the ratings-based measure of government support that we use in our baseline results. Overall, our analysis and the results of Demirgüç-Kunt and Huizinga (2010) provide complementary evidence of investors’ perception that governments and banks are closely related.

The remainder of the paper is structured as follows. Section 2 explains the channels that connect governments and banks. Section 3 explains our data set, and Section 4 outlines our empirical methodology. We present our main results regarding the effects of sovereign rating downgrades in Section 5, and explore potential nonlinearities 
of these effects in Section 6. Section 7 reviews related literature, and Section 8 concludes.

\section{CONCEPTUAL FRAMEWORK: TRANSMISSION CHANNELS BETWEEN SOVEREIGN RISK AND BANKS}

The global financial crisis and its aftershocks in Europe are the latest reminders of the close relationship between sovereign credit risk and the banking sector. Sovereign credit risk could affect the banking sector through various channels. Our empirical analysis in subsequent sections focuses on three transmission mechanisms.

First, the fiscal condition of the government could directly impact domestic economic activity, which in turn affects the demand for financial services. A sovereign rating downgrade typically increases the cost of issuing debt for the government, forcing it to borrow at a faster pace, raise more taxes, or cut public expenditures. All these actions forced onto the government by higher borrowing costs are likely to put a drag on economic activity and reduce the profitability of banking activities. For example, higher taxes could reduce investment and consumption, thus depressing the demand for loans.

Second, banks around the world tend to hold substantial volumes of domestic government debt in their portfolios. Therefore, sovereign rating downgrades make balance sheets in the banking sector more risky. Bank incentives for holding government debt are partly explained by the safe-asset treatment enjoyed by government debt in riskbased bank capital regulation. Moreover, government debt is widely accepted as collateral in secured borrowing markets and is used for central banks operations, making government debt a very liquid asset. Bolton and Jeanne (2011) report that domestic 
banks in Europe and Japan held about 15 and 50\%, respectively, of domestic government debt in 2009. Consistent with the importance of this channel of transmission from strains in government finances to the banking sector, Gennaioli, Martin, and Rossi (2012) find that government defaults are associated with larger contractions in credit supply in countries in which banks hold more government bonds.

Third, governments are commonly willing to support banks to prevent their failure, particularly institutions that are perceived to be "too big to fail" or systemically important. A sovereign rating downgrade, by casting doubt on the willingness or ability of the government to support failing banks, reduces the value of the (explicit or implicit) guarantee, thus increasing investor concerns about banks. Governments are willing to bail out troubled banks, because widespread bank failures are considered very costly in terms of output (Kaminsky and Reinhart 1999, Dell'Ariccia, Detragiache, and Rajan 2008). The benefits of the guarantee enjoyed by banks are reflected in part in lower borrowing costs for the bank (Committee on the Global Financial System (CGFS) 2011, Ejsing and Lemke 2011), benefits that could shrink when governments experience financial strains.

Because banks have become more complex institutions in recent decades, it is possible that our list of transmission channels is not exhaustive. Even so, our empirical analysis focuses on the three transmission channels that have concentrated the attention of policy makers (see, e.g., CGFS 2011). Our objective in this paper is to exploit variation in bank stock returns after sovereign rating downgrades to learn about the empirical contribution of these three transmission channels. 
Finally, it is important to note that the financial condition of the banking sector could feedback into the fiscal health of the government, through the costs of bailouts. For example, Acharya, Drechsler, and Schnabl (2011) highlight the possibility that troubles in the banking sector could deteriorate public finances, and they find that credit default swap (CDS) spreads of banks and those of governments tend to move more closely together after the announcement of financial sector bailouts. However, Borensztein and Panizza (2009) find that sovereign defaults significantly increase the probability of a future banking crisis, but banking crisis do not increase the probability of a sovereign default to the same degree. ${ }^{2}$ To interpret our results in later sections, it is important to note that to the extent that fiscal strains for the government are caused by troubles in the banking sector, we expect sovereign ratings downgrades to be well anticipated and reduce their informational content. This should bias our estimates of stock market reaction towards zero, and in fact work against our regressions finding any significant results.

\section{DATA}

\subsection{Sovereign Rating Events}

We collect data on sovereign bond rating changes on long-term foreign currencydenominated debt from January 1995 to May 2011. We use changes in sovereign credit ratings from S\&P, as they appear to be relatively more frequent, tend not to be

\footnotetext{
${ }^{2}$ Granger causality tests (not reported here) for changes in banking sector CDS spreads and in sovereign CDS spreads, in first differences, for the countries and years covered in our analysis tend to be relatively more supportive of causality running from CDS spreads of governments to CDS spreads of banks than in the opposite direction. To be clear, however, neither direction of causality can be rejected for all countries in the sample. For these tests, we use daily data on a 5-year banking sector CDS index and the 5-year sovereign CDS. We consider 1 to 5 day lags for each variable in the test, and construct the banking sector CDS index as an average of individual bank CDS for the country, weighted by each bank's assets.
} 
anticipated by the market, and tend to precede the changes of other rating agencies (Brooks et al. 2004, Gande and Parsley 2005). ${ }^{3}$

We transformed credit ratings and credit outlooks into a numerical scale, using the table in the Appendix. To capture any meaningful changes in ratings, we define the total numerical value of a rating as the sum of the numerical value of an alphabetical rating and the numerical value of the credit outlook. Then, a Positive event is defined as the absolute value of an increase in the total numerical value of a rating, while a Negative event is the absolute value of a decrease in the total numerical value of a rating. We define positive and negative events separately, to allow for asymmetric effects to upgrades and downgrades.

The numerical conversion of credit ratings and outlooks is similar to that in Appendix B of Gande and Parsley (2010). However, we use a slightly different numerical scale for outlook changes, which identifies more changes in credit ratings and outlooks as events. The advantages of our adjusted scale are illustrated by the following example. On April 30, 2008, the rating of Brazil's long-term foreign-currency bond was upgraded from $\mathrm{BB}+/$ Positive outlook to BBB-/Stable outlook. According to the scale in Gande and Parsley (2010), the numerical value of the credit rating prior to April 30, 2008, is 12 , which is obtained by the sum of $11(\mathrm{BB}+)$ and 1 (Positive outlook). Despite the upgraded rating, the numerical value of the new rating in that scale is also 12 after April 30 , 2008, since the numerical adjustment for a stable outlook is zero. Using the scale in Gande and Parsley (2010), the change in ratings for Brazil on April 30, 2008, would not be considered a positive event and would be dropped from the sample.

\footnotetext{
${ }^{3}$ Our results are robust to using sovereign credit ratings from Moody’s.
} 
In contrast with Gande and Parsley (2010), we assign numbers with absolute values that are less than 1 to different outlook categories. As detailed in the Appendix, we assign values from -0.2 to 0.2 in increments of 0.1 to five different outlook stages ascending from negative outlook (-0.2) to positive outlook (0.2). Because of our methodology, we are able to identify 50 more events compared to the methodology of Gande and Parsley.

\subsection{Bank Stock Returns}

We calculate daily returns using the daily total return index from Datastream for all stocks from 37 countries from January 1995 to May 2011. ${ }^{4}$ According to the classification developed by the International Finance Corporation of the World Bank Group, of the 37 countries represented in our sample, 13 are advanced economies (Australia, Belgium, Canada, Denmark, Finland, Greece, Hong Kong, Ireland, Italy, Japan, Spain, Sweden, and the United Kingdom), and the remaining are emerging markets (Argentina, Brazil, Chile, China, Colombia, Czech Republic, Hungary, India, Indonesia, Israel, Malaysia, Mexico, Pakistan, Peru, the Philippines, Poland, Portugal, Russia, South Africa, South Korea, Taiwan, Thailand, Turkey, and Venezuela). We also obtain a global market return index from Datastream.

We exclude from our sample bank stocks without data on market capitalization and the book-to-market ratio at the end of the year prior to an event. We choose only stocks traded on major exchanges that have the majority of stocks for that country. ${ }^{5}$ We

\footnotetext{
${ }^{4}$ The return index for each stock is built under the assumption that dividends are reinvested. It is also adjusted for stock splits.

${ }^{5}$ Most countries have one major exchange, except China (Shanghai and Shenzhen stock exchanges).
} 
use only common stocks and exclude stocks with special features, such as depository receipts, real estate investment trusts, and preferred stocks.

We do not require bank stocks to have observations for the entire period of our study (1995-2011) to be included in our sample. Similar to Ince and Porter (2006), we set the daily return as "missing" if any daily return of at least $100 \%$ is reversed the following day. Foreign exchange rate data are also obtained through Datastream. ${ }^{6}$

Table 1 shows the number of positive and negative events for each country in our sample. Table 1 also reports the number of total events (positive and negative), the number of big-positive events (upgrades by two or more in the numerical scale), and the number of big-negative events (downgrades by two or more in the numerical scale). Turkey experienced more events (positive and negative) in our scale than any other country in our sample (20 times), followed by Brazil (17 times), and India and Venezuela (14 times each). Four countries experienced big-positive events, while seven countries suffered big-negative events in the sample. For each country in our analysis, Table 2 reports the number of banks and the number of stock-event observations in our sample. Banks from Italy, Japan, and South Korea account for about 25\% of the sample.

[Tables 1 and 2 about here]

\subsection{Government-Provided Support to Banks}

We measure expected government support to banks using bank-specific ratings information from Moody’s. Since 1995, this rating agency has assigned bank financial

\footnotetext{
${ }^{6}$ Since the exchange rate against the U.S. dollar does not cover all of the sample periods for some countries but the rate against the U.K. sterling does so, the U.S. dollar exchange rate is calculated by using the crossrates through the pound sterling.
} 
strength ratings (BFSRs) to banks in about 90 countries. According to Moody's, BFSRs "represent Moody's opinion of a bank's intrinsic safety and soundness” (Moody’s Investors Service 2007a). More important, this measure does not include any external support that a bank may receive from its parent, other institutions under a cooperative or mutual arrangement, or the government.

Moody's also assigns a bank deposit rating to the banks it rates. The deposit rating is the rating agency's opinion of a bank's ability to repay its deposit obligations punctually and incorporates both the bank’s BFSR and Moody's opinion of any external support. ${ }^{7}$ For most banks rated by Moody's, external support is mainly explained by systemic support expected from central governments. For example, in November 2011, Moody’s assigned a BFSR to a total of 1,022 banks (Moody’s Investors Service 2011a). Of this group, Moody's considered that 470 banks benefitted from some type of support from central governments. By contrast, Moody’s assigned far fewer banks some level of support from their parent companies (246 banks), from cooperative arrangements (28 banks), or from local and regional governments (11 banks). The relative importance of systemic support and the magnitude of the ratings lift provided by central governments suggest that systemic support expected from central government is the most prevalent form of ratings support. In our empirical analysis we use the difference between the bank's deposit rating and its BFSR as a measure of the expected government support to that individual bank.

\footnotetext{
${ }^{7}$ Moody's calls this methodology a joint-default analysis (Moody's Investors Service 2007b). Bank failures are typically less frequent than those of non-financial corporations. An explanation for this finding is that banks are more likely to receive support from external sources, including the government. The jointdefault analysis methodology embeds this empirical finding by determining a bank's credit rating using the probability of failure of the bank conditional on the expected external support that the bank may receive.
} 
As noted by Moody's Investors Services (2007a), the potential government support of a bank depends on two factors: the national policy with respect to bank resolutions and the importance of the bank within a country. Policy towards bank resolutions is a country-specific factor that Moody's evaluates by focusing on a country's history of deposit defaults and the importance and strength of the banking system. For dollarized economies, Moody's also takes into account the degree of banking dollarization. This set of factors is important to capture the overall propensity and ability of a government to provide support to its banks through capital injections, liquidity provisions, and regulatory forbearance, amongst other actions. In addition, some banks are more likely to receive support than others during a crisis. To capture these crosssectional differences in the likelihood of support, Moody's takes into account whether a bank is partially or fully owned by the government and the importance of the bank within the banking sector and the overall payments system of a country.

In our main specifications, the bank-specific measure of expected government support is defined as the difference (in rating notches) between a bank's long-term foreign currency deposit rating and its BFSR. Larger (more positive) values of this measure imply that governments are more likely to support the bank when it runs into trouble, while smaller (more negative) values indicate a lower probability of support or that a government intervention may decrease the probability of repayment for bank creditors. As a robustness check, we also consider the probability of government support of a bank, as defined in Gropp, Hakenes, and Schnabel (2011), as an alternative measure 
of expected government support. ${ }^{8}$ To calculate this alternative measure of support, we use actual default frequencies from Moody’s Investors Service (2011b) to back out the probability of government support using the BFSR and foreign currency deposit rating of a bank.

Table 3 presents summary statistics by country for our main measure of expected government support. As shown in the first column, average government support of banks in the sample measured in ratings notches ranges roughly from -5 notches to 5 notches. In countries where the government has used deposit freezes, capital controls, or other measures that have affected these creditors in the past (e.g., Argentina and Brazil imposed deposit freezes in 2001 and 1990, respectively, with large losses to depositors), systemic support of a bank is likely to be negative. ${ }^{9}$ The table also shows that rating support across banks and time within a country also varies markedly, as suggested by the maximum and minimum values reported in the last two columns. Figure 1 plots the median government support of banks over time, in rating notches, for the sample of financial institutions included in our main estimations. As shown in the figure, government support has increased during periods of banking distress like the Asian, Russian, and Japanese crises at the end of the 1990s, the Argentine sovereign crisis in the early 2000s, and, more recently, the global financial crisis after 2007. This variation across banks and time is important to identify the effect of sovereign rating

\footnotetext{
${ }^{8}$ These authors use Fitch Ratings to analyze the relation between government support, competition, and bank risk-taking. In another related study, Gropp, Vesala, and Vulpes (2006) test the usefulness of equity signals, controlling for government support, as indicators of bank distress.

${ }^{9}$ Moody's Investors Service (2008) summarizes episodes in which sovereign defaults were accompanied by policies that affected debt servicing of domestic and foreign bank depositors and other creditors.
} 
announcements on the stock returns of banks with different levels of expected government support within a country.

[Table 3 and Figure 1 about here]

To confirm that the ratings-based measure of government support from Moody's that we use in our main analysis in Section 5 is effectively capturing the constraints and incentives of governments in supporting banks, we estimate the following regression:

$$
\text { Support }_{i j t}=\alpha+\beta_{1} \text { Liabilities }_{i j t} / G D P_{j t}+\beta_{2} \text { Deficit }_{j t}+\lambda_{i}+\mu_{t}+\varepsilon_{i j t} \text {, }
$$

where Support ${ }_{i j t}$ is the average over year $t$ of the ratings-based measure of government support for bank $i$, which is headquartered in country $j$. Liabilities ${ }_{i j t} / G D P_{j t}$ represents the ratio of bank i's total liabilities to GDP, which measures the systemic importance of bank $i$ within country $j$. De ficit $_{j t} / G D P_{j t}$ is the general government's budget deficit in country $j$ expressed as a fraction of GDP. Finally, $\lambda_{i}$ and $\mu_{t}$ represent bank and year fixed effects, respectively. Country-level data are taken from the IMF, and bank-level variables are taken from Bureau van Dijk’s Bankscope database. We estimate equation (1) using the same sample of banks that we consider in our main analysis and that we describe in Section 3.

Table 4 summarizes the results of estimating equation (1). As a benchmark, we report the results of estimating an OLS regression without fixed effects in column 1 . The statistically significant coefficient on the measure of systemic size suggests that banks that are larger relative to their domestic economies are expected to receive stronger government support. Similarly, the statistically significant coefficient on the budget 
deficit variable indicates that banks are expected to receive less government support in countries with higher budget deficits, which may reflect that governments running higher budget deficits have less fiscal flexibility to support banks on a discretionary basis. The estimate in column 2 suggests that the relationship between systemic size and the ratingsbased measure of government support is robust to controlling for bank and year fixed effects and for clustering standard errors at the country-year level. However, the relationship between budget deficits and government support is no longer statistically significant. The regression reported in column 3 indicates that the results for the systemic size variable are similar if we measure bank size in terms of bank assets relative to GDP, instead of bank liabilities relative to GDP. Finally, the regression in column 4 includes additional control variables to equation (1): an indicator variable that equals one for banks with more than $10 \%$ of government ownership, a measure of absolute bank size (log assets), and the interaction of the budget deficit with the systemic size variable. The coefficient on the systemic size variable remains positive and statistically significant after including these additional controls. Moreover, the coefficient on the interaction between government deficits and bank systemic size is negative and statistically significant. A possible interpretation of these findings is that systemically important banks are expected to receive support, but that such expected support is relatively weaker in countries where governments have no fiscal room for maneuvering because of high budget deficits. ${ }^{10}$

[Table 4 about here]

Overall, the results in Table 4 suggest that our baseline ratings-based measure of government support is a reasonable proxy for the ability and willingness of governments

\footnotetext{
${ }^{10}$ These results are consistent with the findings of Demirgüç-Kunt and Huizinga (2010).
} 
to help financial institutions. In subsequent sections, we exploit variation across banks in the measure of government support to understand the effects of sovereign debt rating changes on the banking sector's stock returns.

\section{METHODOLOGY}

We use traditional event study techniques (Brown and Warner 1985) to test the effect of sovereign rating changes on the stock returns of banks with different levels of ex-ante government support. More specifically, we want to assess whether sovereign rating changes convey new information about the ability of governments to support domestic banks, and thus we want to test the impact of this new information on the stock returns of banks. ${ }^{11}$ Measuring bank-level stock returns instead of an aggregate index of bank stock prices allows us to exploit variation across banks to better understand the link between sovereign credit risk and the banking sector. We focus on the reaction of stock prices, as opposed to bond yields, because stocks are more frequently traded than bonds.

As in any event study analysis, to assess the stock market reaction to an event (a sovereign rating change in our case), we need to compute the abnormal or excess stock returns of banks during the event. Therefore, in the first step we compute abnormal returns as the difference between realized returns and the expected returns implied by a market model. More formally:

$$
r_{i t}=R_{i t}-\hat{\alpha}_{i}-\hat{\beta}_{i} R_{m t}
$$

\footnotetext{
${ }^{11}$ As noted by the CGFS (2011), sovereign rating changes often precede changes in bank ratings. Sovereign ratings convey information not only about macroeconomic conditions and the fiscal soundness of the sovereign, but also about the ability of the government to support the banks. This is reflected in the ratings of banks.
} 
where $r_{i t}$ is the excess return for bank $i$ at time $t ; R_{i t}$ is the realized stock return of bank $i$; $R_{m t}$ is the market return. Finally, for each bank before a sovereign event at time $T, \hat{\alpha}_{i}$ and $\hat{\beta}_{i}$ are the intercept and slope coefficients, respectively, of an OLS regression of bank $i$ 's stock returns on a constant and the market return estimated using daily data ranging from 75 days prior to the event to 6 days prior to the event. In other words, we consider an estimation window of $[T-75, T-6]$ before each event in our sample. ${ }^{12}$ Finally, we compute excess returns over a $[-1,1]$ event window.

A question remains about the market return that should be used to compute excess returns. As noted by Karolyi and Stulz (2003), there are two alternatives in estimating the market model for a cross-country sample of stocks. The first estimates $\hat{\alpha}$ and $\hat{\beta}$ in the market model using a domestic market index, while the second uses a world market index. These authors label these two models the "domestic CAPM" and the "world CAPM," respectively. The validity of each model depends on the assumptions about investors' access to foreign assets. If investors can only hold domestic assets, the "domestic CAPM" is a valid model, while if investors can hold domestic and foreign assets the "world CAPM" must hold, and in this instance the "domestic CAPM" introduces systematic pricing mistakes. Given the considerable number of equity market liberalizations that have occurred in the last two decades (see Bekaert and Harvey 2005), it is more likely that the "world CAPM" is a more accurate representation of equity returns pricing in our sample. Although we show results using both models, our

\footnotetext{
${ }^{12}$ A bank must have at least 50 observations in the estimating window to be included in our sample.
} 
preferred results are derived using the "world CAPM” model (as in Martell 2005 and in Lee et. al. 2010).

After calculating bank-level excess returns, we test whether sovereign news events have significant effects on bank stock returns. In our first specification, we test this hypothesis by estimating the following equation:

$$
r_{i j t}=\alpha+\beta_{1} \text { Positive event }_{j t}+\beta_{2} \text { Negative event }_{j t}+\delta X_{i j t-1}+\gamma Z_{j t-1}+\theta_{j}+\mu_{t}+\varepsilon_{i j t} \text {, }
$$

where $r_{i j t}$ represents the excess stock return of bank $i$ located in country $j$ in period $t$ over the $[-1,1]$ window (in days). Positive event (Negative event) is defined as the absolute value of rating and outlook changes if the change is positive (negative), and zero otherwise. ${ }^{13}$ The vector $X_{i j t-1}$ represents a set of bank-specific controls: The lagged log value of the bank's market capitalization in U.S. dollars, the lagged log value of the book-to-market ratio, a measure for the volatility of the bank’s stock return, and indicator variables for the lagged level of a bank's BFSR. $Z_{j t-1}$ is a vector of indicator variables for the lagged level of a country's sovereign debt rating. Finally, $\theta_{j}$ and $\mu_{t}$ are country and time fixed effects. We estimate equation (3) using weighted least squares (WLS) and cluster standard errors by country-event. The coefficients of interest in this equation are $\beta_{1}$ and $\beta_{2}$, which capture the aggregate informational content of sovereign news events on banks’ excess returns.

\footnotetext{
${ }^{13}$ Previous studies have found that negative rating events, such as downgrades, lead to significant changes in sovereign bond spreads, while positive events generally do not have notable effects on spreads (Gande and Parsley 2005). We separate the effect of positive and negative rating events in our main specifications to allow for asymmetric effects. Perfectly symmetric effects are a special case of our specification, in which the coefficients on Positive event and Negative event are equal in magnitude and opposite in sign.
} 
Our second set of tests focuses on the effect of sovereign rating events on bank excess returns through a potential change in the government support of banks. As noted in previous sections, the capacity of governments to support their banks is an important component of the perception by investors or rating agencies of the support that a bank may receive in periods of stress. Sovereign ratings events provide new information about this capacity, as sovereign ratings provide information about the soundness of government finances. As such, if stock returns price the benefits of government support, potential changes in this government support due to changes in the condition of the sovereign should have significant effects on banks' excess stock returns. More explicitly, we test this hypothesis using the following specification:

$$
\begin{aligned}
& r_{i j t}=\alpha+\beta_{1} \text { Positive event }_{j t}+\beta_{2} \text { Negative event }_{j t}+\beta_{3} \text { Support }_{i j t} \\
& +\beta_{4} \text { Positive event }_{j t} \times \text { Support }_{i j t}+\beta_{5} \text { Negative event }_{j t} \times \text { Support }_{i j t}, \\
& +\delta X_{i j t-1}+\gamma Z_{j t-1}+\theta_{j}+\mu_{t}+\varepsilon_{i j t},
\end{aligned}
$$

where Support is the expected government support for bank $i$ as of the month prior to the sovereign rating event, in rating notches, as defined in Section 3. All other variables are defined as in equation (3). The coefficients of interests are $\beta_{4}$ and $\beta_{5}$. They capture the additional effect of a positive or negative rating event on banks with different levels of support. If a negative rating event increases the likelihood that a bank will have less support in the future, banks with more government support should experience a larger decrease in excess returns and $\beta_{5}$ should be negative. This result only holds if government support is priced into equity returns. 


\section{MAIN RESULTS}

As a benchmark to gauge the magnitude of the stock market effects in this section, the regressions in Table 5 report the effect of sovereign rating changes on the stock returns of domestic price indexes (columns 1 and 2) and of domestic banks (columns 3 and 4). The coefficient on positive events is generally not statistically significant. By contrast, the coefficient on negative events is statistically significant and implies a negative return of roughly $2 \%$ around the announcement of a sovereign rating downgrade (or a negative event, defined in Section 3) for both domestic stock price indexes and the stock prices of domestic banks. This result confirms the findings in Brooks et al. (2004) and indicates that sovereign rating changes have a significant effect on the performance of domestic stock markets, mostly explained by the negative effect of downgrades.

\section{[Table 5 about here]}

In terms of the transmission mechanisms operating from sovereign credit downgrades to banks, the results in Table 5 suggest that banks, like other domestic firms, are affected by a sovereign rating downgrade, likely because the financial situation of the government has a direct impact on economic activity. The results, reported in columns 3 and 4 in Table 5, are related to the stock returns of the average bank. In the rest of this section, we exploit cross-sectional differences in bank characteristics to gauge the importance of other channels that could run from sovereign rating changes to the banking sector. 
The next transmission channel that we consider is the potential government support provided to banks. As we discuss in Sections 2 and 3, investors typically expect banks in trouble to receive support from their governments, because widespread failure of financial institutions can have devastating effects on economic activity by, for instance, restricting the availability of credit, possibly causing or deepening a recession. However, not all banks are expected to receive government support to the same extent. We use the ratings-based measure of government support introduced in Section 3 to capture differences in expected government support across banks. The regressions in Table 6 report the results of running regressions of bank excess returns on sovereign rating changes and their interaction with the ratings-based measure of government support.

[Table 6 about here]

The dependent variable in columns 1 and 2 of Table 6 is the excess stock return of the bank computed with a market model that uses the domestic stock price index as the market return. Similarly, the dependent variable in columns 3 and 4 is the excess stock return of the bank computed with a market model that uses a world stock price index as the market return. The regressions in columns 1 and 3 report our estimates of equation (3), and the regressions in columns 2 and 4 report our estimates of equation (4). Regardless of the stock price index used as the market return to compute excess returns, we estimate the interaction coefficients between negative events and the ratings-based measure of government support to be negative and statistically significant. Moreover, the economic magnitude of this effect is also sizable. For example, using the relatively more conservative point estimates in column 2, a 1-standard deviation increase in government support (3.5 notches) is associated with $1 \%$ lower excess stock returns after the 
announcement of negative events. This is a considerable effect when compared with the $2 \%$ negative return after negative events on domestic stock price indexes or on average bank returns reported in Table 5. In other words, the average negative effects of sovereign rating downgrades reported in Table 5 mask a significant amount of crosssectional heterogeneity, and part of the cross-sectional heterogeneity is explained by differences in perceptions regarding the extent to which banks are expected to be supported by their governments.

Overall, the results in Table 6 lend evidence of a transmission channel from sovereign rating changes to banks that operates through the support that investors expect governments to provide to domestic banks. This effect operates over and above any economy-wide effects derived from sovereign rating changes.

The third transmission mechanism that we consider in this section operates through bank holdings of domestic government debt. Unfortunately, detailed bank-level data on domestic government debt holdings are sparse. However, as part of the bank stress tests conducted by European bank regulators in 2011, the European Banking Authority published bank-level data on government debt holdings as of year-end 2010 for banks in 21 countries, mostly in the euro area. ${ }^{14}$ We merge the data on government debt holdings for the subset of banks in our sample included in the stress tests, and then consider the effect of bank holdings of domestic debt on bank excess returns around sovereign rating changes. More formally, we expand equation (4) to include domestic government debt holdings expressed as a fraction of tier 1 capital and its interaction with

\footnotetext{
${ }^{14}$ See http://www.eba.europa.eu/EU-wide-stress-testing/2011/2011-EU-wide-stress-test-results.aspx.
} 
the variables for positive and negative events. The results of running these regressions are reported in Table 7.

[Table 7 about here]

The dependent variable in column 1 (column 2) of Table 7 is bank excess stock returns computed over the market model using the domestic stock price index (world price index) as the market return. The estimated coefficients on the interaction between holdings of government debt and positive events are positive and statistically significant across specifications, suggesting that stock market investors interpret sovereign rating upgrades as good news for banks that hold relatively large volumes of government debt in their portfolios as a fraction of their regulatory capital. The economic magnitude of this effect is relatively modest compared with the negative effects of sovereign rating downgrades. Using the point estimates of the regression in column 1, a 1-standard deviation increase in bank holdings of government debt (about 1.004 times tier 1 capital), is associated with $0.3 \%$ higher excess stock returns after the announcement of a positive event.

The results in Table 7 also indicate that the coefficients on the interaction terms between negative events and expected government support remain negative and statistically significant even after controlling for bank holdings of government debt. These findings are consistent with holdings of government debt and measures of expected government support both explaining cross-sectional variation in the reaction of banklevel stock returns to news about sovereign debt ratings. Our results suggest that investors believe that the stock market valuation of banks is connected to sovereign credit 
risk through three channels: an economy-wide effect, a reduction in the value of government-provided guarantees, and bank-level holdings of government debt. Our finding also indicates that the significant effects of news on sovereign credit ratings on bank stock market valuations that operate through perceptions of government support are robust to controlling for other channels that connect banks with governments in the minds of investors.

In Table 8, we consider two important robustness checks to our estimate of a negative and significant interaction between expected government support and negative events associated with sovereign rating downgrades. Columns 1 and 2 consider an alternative measure of expected government support. In particular, we use support ratings assigned by Moody’s to construct a bank-specific support probability following the methodology proposed in Gropp, Hakenes, and Schnabel (2011). This robustness check is particularly useful to address concerns about nonlinear effects that are ignored when measuring government support using numeric rating scales with values that increase always by the same amount from one notch of the ratings scale to the next one above, regardless of the initial rating. The support probability measure based on the work of Gropp, Hakenes, and Schnabel (2011) assigns larger values to the expected government support when banks have relatively lower standalone ratings. ${ }^{15}$ As reported in columns 1 and 2, we estimate that the interaction coefficients between the variables for negative events and the support probability measure are negative and statistically

\footnotetext{
${ }^{15}$ For example, a one-notch bump in ratings due to expected positive government support for a bank rated AA+ practically does not change the expected support probability for the bank. By contrast, a one-notch bump in ratings due to expected support for a bank rated BB, increases the expected support probability by 40 percentage points.
} 
significant, which suggest that our baseline results in Table 6 are robust to alternative measures of government support that account for nonlinear effects of expected support.

[Table 8 about here]

The second robustness check we consider in Table 8 is the length of the event window we use to compute bank excess stock returns. In columns 3 and 4 we report results for regressions in which the dependent variables are bank excess returns computed using a month-long window around sovereign rating change events starting 5 days prior to the event. The interaction coefficients between the ratings-based measure of government support and the variable for negative events is negative, although it is not always statistically significant, which suggests that the effects of sovereign rating downgrades on stock market returns of banks expected to receive support by the government may not necessarily be very long lasting.

With longer event windows, it is more likely that other confounding factors pollute our estimates of the market reaction to sovereign rating changes. Moreover, longer event windows make it more likely that we conflate the direct effect of the sovereign rating change (which is what we want to capture in this paper) with the effects of any adjustment that banks or governments could make to offset the consequences of the rating change. Because of these concerns, our preferred specifications use shorter event windows, like the results reported in Table 6. 


\section{NONLINEAR EFFECTS OF SOVEREIGN EVENTS ON BANKS' EXCESS RETURNS}

In this section we analyze whether sovereign rating events nonlinearly affect banks' excess returns through potential changes in the perceived level of government support. First, we analyze the informational content of large sovereign rating events. We define a large rating event as a movement of at least two notches along S\&P’s rating scale. Large events are likely unexpected and provide more information about the condition of the sovereign, and thus could have larger effects on bank stock return through investors' expectations of government-provided support.

The results in Table 9 allow us to test whether bigger events have stronger effect than smaller events. The specification is similar to equation (4), except that positive and negative events are each split into large and small events. The coefficients of interest are the interaction terms between the measure of expected government support and the sovereign rating events. These results show that big negative events have a larger effect on excess returns for those banks with more government support. In contrast, small negative events and positive events do not appear to have a statistically significant effect on excess returns when interacted with the level of government support.

[Table 9 about here]

Another potential nonlinearity is associated with rating changes that cross the investment-grade threshold (between ratings of $\mathrm{BBB}-$ and $\mathrm{BB}+$ ). Cumulative average default rates could be nonlinearly increasing (decreasing) as the rating level is lower (higher). As noted by Standard \& Poor's Rating Services (2012), the largest jump in 
default frequencies happen between investment grade rating levels and non-investment grade levels. This nonlinear pattern in default frequencies may imply that changes between investment and non-investment grade provide additional news about the ability of governments to provide support to their banks. Unfortunately, we are not able to test this nonlinearity directly since we practically have no rating changes crossing the investment-grade threshold in our sample.

Nonlinearities may also be related to bank characteristics like the funding model of a bank, its activities, or its rating level. Table 10 shows results that test whether these characteristics significantly affect the impact of sovereign announcement on banks' excess returns. The first two columns test whether banks' reliance on deposit funding mitigates the effect of sovereign events on excess returns for banks with difference levels of government support. Column 1 shows that the effect of negative events on excess returns remains negative and statistically significant for banks with more government support after adding the ratio of deposits over total liabilities of banks, which measures bank reliance on deposit funding. In column 2, we add interactions of the measure of reliance on deposits with the sovereign rating event variables and our measure of expected government support. We find that banks that are more reliant on deposit funding appear to be more resilient to negative sovereign rating events although their excess returns are lower on average. The interaction between negative event and support remains negative and with a similar coefficient, but it is no longer statistically significant. More important, the triple interaction term between support, deposit reliance, and negative event is not statistically significant. This may imply that the effect of 
government support and sovereign rating news does not vary significantly with banks’ reliance on deposit funding.

\section{[Table 10 about here]}

In columns 3 and 4, we test whether banks' activities affect the relation between government support and excess returns during sovereign rating events. In particular, these specifications include the ratio of non-interest income to total assets, a proxy for the size of a bank's non-traditional banking activities. We find that excess returns for banks with larger government support decrease during negative rating events, but this decrease is smaller for banks with more non-interest income. This result is suggestive of some potential advantages for banks with more diversified income streams. These banks may be more resilient to changes in government support.

Another source of nonlinearity is the solvency condition of the banks. Financial institutions that are closer to default suffer more from a potential change in government support than those that are in better financial condition. The specifications in columns 5 and 6 explore this hypothesis by including the lagged level of a bank's BFSR, which we map to a numeric scale ranging from 1 (weakest rating) to 13 (strongest rating). The results in column 6 suggest that negative sovereign events reduce excess returns for banks with more government support, but the decrease in return is smaller for banks with a higher BFSR. This finding provides evidence that a bank's initial solvency condition is important to assess whether the bank will suffer from a decrease in government support.

In Table 11, we report the results of separately estimating our baseline regressions (equation (4)) for the subsamples of advanced economies and emerging markets, as 
classified by the International Finance Corporation of the World Bank. The regressions on the subsample of emerging markets are reported in columns 1 and 2, while the regressions on the subsample of advanced economies are reported in columns 3 and 4 . We find that the interaction between our ratings-based measure of expected government support and the variable for negative rating events are generally negative and statistically significant across samples and specifications, but more consistently so in the sample of advanced economies. Moreover, in absolute value, the estimated magnitude of the interaction coefficient is larger in the regressions for advanced economies. ${ }^{16}$

[Table 11 about here]

Governments in advanced countries tend to have more fiscal flexibility to support troubled domestic banks, which possibly associated with the greater ability of governments in advanced economies to access international credit markets. Consistent with this view, our ratings-based measure of expected government support reported in Table 3 is on average higher in advanced economies. The results in Table 11 thus suggest that the value of expected government support for banks depends on the credibility and strength of the (implicit) guarantor.

\section{RELATED LITERATURE}

Our paper is related to previous studies that analyze the effect of sovereign credit rating events on equity market returns. For example, Kaminsky and Schmukler (2002) and Brooks et al. (2004) study the effects of sovereign rating changes on aggregate stock

\footnotetext{
${ }^{16}$ In results not reported here, the triple interaction coefficient between expected government support, the variable for a negative event, and a dummy for advanced economies are also statistically significant in a regression for the overall sample.
} 
markets, and Martell (2005) documents the effects of sovereign rating changes on individual stock returns. In addition, Lee, Sapriza, and Wu (2010) explore how country characteristics affect the link between sovereign rating changes and stock returns. Our work contributes to this literature by focusing on the effect of sovereign ratings on banks, and exploit variation across banks (for example, in terms of expected government support) in their response to these events.

A second set of related studies analyzes the effect of sovereign rating changes beyond equity markets. These studies suggests that sovereign rating changes affect bond yields (Cantor and Packer 1996, Larrain, Reisen, and von Maltzan 1997), private-sector debt ratings and interest rates (Borensztein, Cowan, and Valenzuela 2007, Cavallo and Valenzuela 2002), and firm-level ratings (Ferri, Liu, and Majnoni 2001, Ferri and Liu 2002). Similarly, Gande and Parsley (2005) find evidence of significant cross-country spillover effects of sovereign rating changes, as rating changes in one country can change sovereign credit spreads in others.

A third set of related papers study the connection between banks and governments. Dermirgüç-Kunt and Huizinga (2010) consider the effect of fiscal balances on equity market valuations of banks, and finds a closer connection for systemically large banks. Acharya, Drechsler, and Schnabl (2011) find that bank troubles may affect the fiscal conditions of governments when investors expect governments to support banks.

\section{CONCLUSIONS}

We study the market reaction of bank stock prices to sovereign rating changes. We find that bank stock prices generally fall after sovereign rating downgrades and are 
little sensitive to sovereign rating upgrades. More importantly, we find significant crosssectional differences in the reaction of bank stock prices to sovereign ratings changes. Our results suggest that the stock market reaction of banks to changes in sovereign credit ratings is likely explained by a combination of factors, including an economy-wide effect that covers banks and other firms, an effect associated with the degree to which investors expect governments to support troubled banks, and bank holdings of government debt. Our most robust finding is that banks that are expected to receive stronger government support experience particularly negative excess returns after the announcement of sovereign rating downgrades. Moreover, we find that these results are stronger for sovereign rating changes in advanced economies, where governments have more flexibility and credibility to support domestic banks.

Overall, our findings are supportive of a channel of transmission of sovereign credit risk operating through expected government-provided support to banks. The results in this paper are thus complementary to studies that link measures of fiscal soundness of governments with bank performance (Demirgüç-Kunt and Huizinga 2010). In contrast with other studies, we focus on stock price reactions during short windows around relatively discrete events, like sovereign rating changes, a methodology that helps us to exclude from our analysis additional factors that may confound the empirical connection between sovereign credit risk and bank performance.

The results of this paper also show that expected government support to banks is perceived to benefit not only bank debt holders, but also their equity holders. Expected government support may increase shareholder value by reducing the cost of debt funding for banks (CGFS 2011, Ejsing and Lemke 2011) and lowering the likelihood of financial 
distress. In other words, expected government support may boost profitability in good states and lower the probability of bad states. However, some studies find that expected bank bailouts may increase risk-taking in the banking sector (e.g., Gropp, Hakenes, and Schnabel 2011, Brandao-Marques, Correa, and Sapriza 2012).

Finally, while we focus on the effect of changes in sovereign credit risk on the banking sector, the impact of the global financial crisis in Europe suggests that widespread bank troubles and subsequent government bailouts may in turn increase government debt and thus deteriorate sovereign credit risk. 


\section{APPENDIX: NUMERICAL SCALE OF SOVEREIGN CREDIT RATINGS}

This table shows the equivalence between our numerical rating scale and S\&P's sovereign bond ratings and credit outlooks. The overall numerical value of credit ratings is the sum of the numerical value of sovereign ratings and the numerical value of the credit outlook.

Panel A

\begin{tabular}{cc}
\hline Sovereign Bond Rating & Numerical Value \\
\hline AAA & 21 \\
AA+ & 20 \\
AA & 19 \\
AA- & 18 \\
A+ & 17 \\
A & 16 \\
A- & 15 \\
BBB+ & 14 \\
BBB & 13 \\
BBB- & 12 \\
BB+ & 11 \\
BB & 10 \\
BB- & 9 \\
B+ & 8 \\
B & 7 \\
B- & 6 \\
CCC + & 5 \\
CCC & 4 \\
CCC- & 3 \\
CC & 2 \\
C & 1 \\
SD, D & 0 \\
\hline
\end{tabular}

Panel B

\begin{tabular}{cc}
\hline Outlook & Numerical Value \\
\hline Positive & 0.2 \\
Watch developing & 0.1 \\
Stable & 0 \\
Watch negative & -0.1 \\
Negative & -0.2 \\
\hline
\end{tabular}




\section{BIBLIOGRAPHY}

Acharya, Viral V., Itamar Drechsler, and Philipp Schnabl. (2011) “A Pyrrhic Victory? Bank Bailouts and Sovereign Credit Risk.” Working Paper, New York University.

Bekaert, Geert, and Campbell R. Harvey. (2005) "Chronology of Important Financial, Economic and Political Events in Emerging Markets." Available online at: http://www.duke.edu/ charvey/Country_risk/chronology/chronology_index.htm.

Bolton, Patrick, and Olivier Jeanne. (2011) "Sovereign Default Risk and Bank Fragility in Financially Integrated Economies.” NBER Working Paper, No.16899.

Borensztein, Eduardo, Kevin Cowan, and Patricio Valenzuela. (2007) "Sovereign Ceilings 'Lite'? The Impact of Sovereign Ratings on Corporate Ratings in Emerging Market Economies.” IMF Working Paper WP/07/75.

Borensztein, Eduardo and Ugo Panizza. (2009) “The Costs of Sovereign Default.” IMF Staff Papers 56, 683-741.

Brandao-Marques, Luis, Ricardo Correa, and Horacio Sapriza. (2012) "International Evidence on Government Support and Risk-Taking in the Banking Sector." Unpublished manuscript.

Brooks, Robert, Robert W. Faff, David Hillier, and Joseph Hillier. (2004) "The National Market Impact of Sovereign Rating Changes.” Journal of Banking and Finance 28, 233-250.

Brown, Stephen J., and Jerold B. Warner. (1985) "Using Daily Stock Returns: The Case of Event Studies.” Journal of Financial Economics14, 3-31.

Cantor, Richard, and Frank Packer. (1996) "Determinants and Impact of Sovereign Credit Ratings.” Federal Reserve Bank of New York Policy Review, 37-54.

Cavallo, Eduardo, and Patricio Valenzuela. (2002) "The Determinants of Corporate Risk in Emerging Markets: An Option-Adjusted Spread Analysis.” IMF Working Paper WP/07/228.

Committee on the Global Financial System (CGFS). (2011) "The Impact of Sovereign Credit Risk on Bank Funding Conditions.” Working Paper 43.

Dell'Ariccia, Giovanni, Enrica Detragiache, and Raghuram Rajan. (2008) "The Real Effect of Banking Crises.” Journal of Financial Intermediation 17, 89-112.

Demirgüç-Kunt, Asli, and Harry Huizinga. (2010) "Are Banks Too Big to Fail or Too Big to Save? International Evidence from Equity Prices and CDS Spreads.” European Banking Center Discussion, No. 2010-15. 
Ejsing, Jacob, and Wolfgang Lemke. (2011) "The Janus-Headed Salvation: Sovereign and Bank Credit Risk Premia during 2008-2009.” Economics Letters 110, 28-31.

Ferri, Giovanni, Li-Gang Liu, and Giovanni Majnoni. (2001) "The Role of Rating Agency Assessments in Less Developed Countries: Impact of the Proposed Basel Guidelines.” Journal of Banking and Finance 25, 115-148.

Ferri, Giovanni, and Li-Gang Liu. (2002) "Do Global Credit Rating Agencies Think Globally? The Information Content of Firm Ratings around the World.” Working Paper University of Bari.

Gande, Amar, and David C. Parsley. (2005) "News Spillovers in the Sovereign Debt Market.” Journal of Financial Economics 75, 691-734.

Gande, Amar, and David C. Parsley. (2010) "Sovereign Credit Ratings, Transparency, and International Portfolio Flows.” Working Paper, Vanderbilt University.

Gennaioli, Nicola, Alberto Martin, and Stefano Rossi. (2012) "Sovereign Default, Domestic Banks, and Financial Institutions.” Working Paper, Universitat Pompeu Fabra.

Gropp, Reint, Hendrik Hakenes, and Isabel Schnabel. (2011) "Competition, Risk-shifting, and Public Bail-out Policies.” Review of Financial Studies 24, 2084-2120.

Gropp, Reint, Jukka Vesala, and Giuseppe Vulpes. (2006) "Equity and Bond Market Signals as Leading Indicators of Bank Fragility.” Journal of Money, Credit, and Banking 38, 399-428.

Ince, Ozgur, and R. Burt Porter. (2006) "Individual Equity Return Data from Thompson Datastream: Handle with Care!” Journal of Financial Research 29, 463-479.

Karolyi, Andrew, and Rene M. Stulz. (2003) "Are Financial Assets Priced Locally or Globally?” in: George M. Constantinides, Milton Harris, and Rene M. Stulz (eds.), Handbook of the Economics of Finance, edition 1, volume 1, chapter 16, pages 975-1020, Amsterdam: Elsevier.

Kaminsky, Graciela L., and Carmen Reinhart. (1999) "The Twin Crisis: The Causes of Banking and Balance-of-Payment Problems.” American Economic Review 89, 473-500.

Kaminsky, Graciela, and Sergio L. Schmukler. (2002) "Emerging Market Instability: Do Sovereign Ratings Affect Country Risk and Stock Returns?” World Bank Economic Review 16, 171.

Larrain, Guillermo, Helmut Reisen, and Julia von Maltzan. (1997) "Emerging Market Risk and Sovereign Credit Ratings." OECD Development Centre Working Papers 124. 
Lee, Kuan-Hui, Horacio Sapriza, and Yangru Wu. (2010) "Sovereign Debt Ratings Changes and Stock Liquidity around the World." Working Paper, Rutgers University.

Martell, Rodolfo. (2005) "The Effect of Sovereign Credit Rating Changes on Emerging Stock Markets.” Working Paper, Purdue University.

Moody’s Investors Service. (2007a) “Bank Financial Strength Ratings: Global Methodology."

Moody's Investors Service. (2007b) "Incorporation of Joint-Default Analysis into Moody’s Bank Ratings: A Refined Methodology.”

Moody’s Investors Service. (2008) “Sovereign Defaults and Interference: Perspectives on Government Risks."

Moody’s Investors Service. (2011a) “Status Report on Systemic Support Incorporated in Moody’s Bank Debt Ratings Globally.”

Moody’s Investors Service. (2011b) “Corporate Default and Recovery Rates, 1920-2010.”

Schich, Sebastian, and Sofia Lindh. (2012) "Implicit Guarantees for Bank Debt: Where Do We Stand?” OECD Journal: Financial Market Trends 1, 1-22.

Standard \& Poor's Rating Services. (2012) “Sovereign Defaults and Rating Transition Data, 2011 Update.” 


\section{Table 1}

\section{Number of events by country}

This table shows the number of sovereign rating events by country between January 1995 and May 2011. We also report counts of the events decomposed as follow: positive (increases in our numerical rating scale), negative (decreases in our scale), big positive (increases of at least two in our scale), big negative (decreases of at least two), and events when the sovereign is upgraded to investment grade or downgraded to non-investment grade.

\begin{tabular}{|c|c|c|c|c|c|c|c|}
\hline Country & $\begin{array}{r}\text { Number of } \\
\text { events }\end{array}$ & $\begin{array}{r}\text { Number of } \\
\text { positive } \\
\text { events }\end{array}$ & $\begin{array}{r}\text { Number of } \\
\text { negative } \\
\text { events }\end{array}$ & $\begin{array}{r}\text { Number of } \\
\text { big positive } \\
\text { events }\end{array}$ & $\begin{array}{r}\text { Number of } \\
\text { big negative } \\
\text { events }\end{array}$ & $\begin{array}{r}\text { Number of } \\
\text { events } \\
\text { (from Inv to } \\
\text { Non-inv) } \\
\end{array}$ & 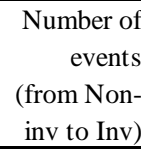 \\
\hline ARGENTINA & 12 & 6 & 6 & 1 & 0 & 0 & 0 \\
\hline AUSTRALIA & 3 & 3 & 0 & 0 & 0 & 0 & 0 \\
\hline BELGIUM & 1 & 0 & 1 & 0 & 0 & 0 & 0 \\
\hline BRAZIL & 17 & 13 & 4 & 0 & 0 & 0 & 1 \\
\hline CANADA & 2 & 2 & 0 & 0 & 0 & 0 & 0 \\
\hline CHILE & 5 & 5 & 0 & 0 & 0 & 0 & 0 \\
\hline CHINA & 7 & 7 & 0 & 0 & 0 & 0 & 0 \\
\hline COLOMBIA & 8 & 5 & 3 & 0 & 0 & 0 & 1 \\
\hline CZECH REPUBLIC & 4 & 3 & 1 & 0 & 0 & 0 & 0 \\
\hline DENMARK & 2 & 2 & 0 & 0 & 0 & 0 & 0 \\
\hline FINLAND & 5 & 5 & 0 & 0 & 0 & 0 & 0 \\
\hline GREECE & 11 & 6 & 5 & 1 & 2 & 1 & 0 \\
\hline HONG KONG & 9 & 8 & 1 & 0 & 0 & 0 & 0 \\
\hline HUNGARY & 12 & 7 & 5 & 0 & 0 & 0 & 0 \\
\hline INDIA & 14 & 8 & 6 & 0 & 0 & 0 & 1 \\
\hline INDONESIA & 13 & 10 & 3 & 1 & 0 & 0 & 0 \\
\hline IRELAND & 7 & 3 & 4 & 0 & 0 & 0 & 0 \\
\hline ISRAEL & 7 & 4 & 3 & 0 & 0 & 0 & 0 \\
\hline ITALY & 6 & 1 & 5 & 0 & 0 & 0 & 0 \\
\hline JAPAN & 8 & 3 & 5 & 0 & 0 & 0 & 0 \\
\hline MALAYSIA & 13 & 8 & 5 & 0 & 0 & 0 & 0 \\
\hline MEXICO & 10 & 7 & 3 & 0 & 0 & 0 & 1 \\
\hline PAKISTAN & 12 & 7 & 5 & 1 & 1 & 0 & 0 \\
\hline PERU & 10 & 7 & 3 & 0 & 0 & 0 & 1 \\
\hline PHILIPPINES & 12 & 5 & 7 & 0 & 0 & 0 & 0 \\
\hline POLAND & 12 & 8 & 4 & 0 & 0 & 0 & 0 \\
\hline PORTUGAL & 9 & 3 & 6 & 0 & 2 & 0 & 0 \\
\hline RUSSIA & 7 & 6 & 1 & 0 & 0 & 0 & 1 \\
\hline SOUTH AFRICA & 6 & 5 & 1 & 0 & 0 & 0 & 1 \\
\hline SOUTH KOREA & 7 & 5 & 2 & 0 & 1 & 0 & 0 \\
\hline SPAIN & 8 & 4 & 4 & 0 & 0 & 0 & 0 \\
\hline SWEDEN & 3 & 3 & 0 & 0 & 0 & 0 & 0 \\
\hline TAIWAN & 7 & 2 & 5 & 0 & 0 & 0 & 0 \\
\hline THAILAND & 9 & 5 & 4 & 0 & 0 & 0 & 0 \\
\hline TURKEY & 20 & 12 & 8 & 0 & 0 & 0 & 0 \\
\hline UNITED KINGDOM & 2 & 1 & 1 & 0 & 0 & 0 & 0 \\
\hline VENEZUELA & 14 & 8 & 6 & 0 & 1 & 0 & 0 \\
\hline Total & 314 & 197 & 117 & 4 & 7 & 1 & 7 \\
\hline
\end{tabular}


Table 2

Number of banks by country

This table shows the number of banks in the sample by country. The last column shows the number of bank-event observations by country.

\begin{tabular}{|c|c|c|c|}
\hline Country & $\begin{array}{r}\text { Number of } \\
\text { banks }\end{array}$ & $\begin{array}{r}\text { Number of } \\
\text { banks (\% of } \\
\text { sample banks) }\end{array}$ & $\begin{array}{r}\text { Number of } \\
\text { bank-event } \\
\text { observations } \\
\end{array}$ \\
\hline ARGENTINA & 6 & 2.3 & 48 \\
\hline AUSTRALIA & 10 & 3.9 & 22 \\
\hline BELGIUM & 1 & 0.4 & 1 \\
\hline BRAZIL & 13 & 5.0 & 82 \\
\hline CANADA & 6 & 2.3 & 12 \\
\hline CHILE & 3 & 1.2 & 14 \\
\hline CHINA & 3 & 1.2 & 17 \\
\hline COLOMBIA & 3 & 1.2 & 21 \\
\hline CZECH REPUBLIC & 2 & 0.8 & 5 \\
\hline DENMARK & 3 & 1.2 & 5 \\
\hline FINLAND & 2 & 0.8 & 10 \\
\hline GREECE & 6 & 2.3 & 53 \\
\hline HONG KONG & 10 & 3.9 & 65 \\
\hline HUNGARY & 1 & 0.4 & 12 \\
\hline INDIA & 14 & 5.4 & 96 \\
\hline INDONESIA & 9 & 3.5 & 37 \\
\hline IRELAND & 5 & 1.9 & 20 \\
\hline ISRAEL & 6 & 2.3 & 42 \\
\hline ITALY & 21 & 8.1 & 82 \\
\hline JAPAN & 30 & 11.6 & 162 \\
\hline MALAYSIA & 7 & 2.7 & 48 \\
\hline MEXICO & 1 & 0.4 & 10 \\
\hline PAKISTAN & 4 & 1.5 & 35 \\
\hline PERU & 2 & 0.8 & 20 \\
\hline PHILIPPINES & 7 & 2.7 & 65 \\
\hline POLAND & 9 & 3.5 & 90 \\
\hline PORTUGAL & 5 & 1.9 & 33 \\
\hline RUSSIA & 7 & 2.7 & 22 \\
\hline SOUTH AFRICA & 1 & 0.4 & 6 \\
\hline SOUTH KOREA & 16 & 6.2 & 64 \\
\hline SPAIN & 10 & 3.9 & 59 \\
\hline SWEDEN & 4 & 1.5 & 10 \\
\hline TAIWAN & 3 & 1.2 & 16 \\
\hline THAILAND & 9 & 3.5 & 65 \\
\hline TURKEY & 14 & 5.4 & 149 \\
\hline UNITED KINGDOM & 4 & 1.5 & 7 \\
\hline VENEZUELA & 2 & 0.8 & 20 \\
\hline Total & 259 & 100.0 & 1,525 \\
\hline
\end{tabular}


Table 3

\section{Government support of banks by country}

This table shows summary statistics for the government support measure (Support) by country. Support is measured as the difference in rating notches between a bank's deposit rating and its Bank Financial Strength Rating .

\begin{tabular}{|c|c|c|c|c|}
\hline Country & $\begin{array}{l}\text { Average } \\
\text { support }\end{array}$ & $\begin{array}{l}\text { Median } \\
\text { support }\end{array}$ & $\begin{array}{r}\text { Maximum } \\
\text { support }\end{array}$ & $\begin{array}{r}\text { Minimum } \\
\text { support }\end{array}$ \\
\hline ARGENTINA & -3.1 & -4 & 0 & -8 \\
\hline AUSTRALIA & 0.2 & 0 & 2 & -1 \\
\hline BELGIUM & 3.0 & 3 & 3 & 3 \\
\hline BRAZIL & -4.7 & -6 & 2 & -10 \\
\hline CANADA & 0.2 & 0 & 1 & 0 \\
\hline CHILE & 0.6 & -0.5 & 6 & -3 \\
\hline CHINA & 0.8 & 1 & 1 & 0 \\
\hline COLOMBIA & -2.4 & -3 & -1 & -4 \\
\hline CZECH REPUBLIC & 2.8 & 2 & 5 & 2 \\
\hline DENM ARK & 0.4 & 0 & 1 & 0 \\
\hline FINLAND & 3.0 & 4 & 5 & 0 \\
\hline GREECE & 1.6 & 1 & 5 & -1 \\
\hline HONG KONG & 1.7 & 0 & 9 & -1 \\
\hline HUNGARY & 0.7 & 0 & 2 & -1 \\
\hline INDIA & -0.9 & 0 & 2 & -4 \\
\hline INDONESIA & -1.5 & -2 & 1 & -4 \\
\hline IRELAND & 2.1 & 0.5 & 8 & -1 \\
\hline ISRAEL & 2.0 & 2 & 4 & 0 \\
\hline ITALY & 0.5 & 0 & 4 & 0 \\
\hline JAPAN & 3.7 & 4 & 9 & 0 \\
\hline M ALAYSIA & 2.4 & 2 & 6 & -2 \\
\hline MEXICO & -0.5 & 0 & 1 & -2 \\
\hline PAKISTAN & -2.0 & -2 & 1 & -6 \\
\hline PERU & -1.1 & 0 & 0 & -4 \\
\hline PHILIPPINES & -1.2 & -1 & 5 & -7 \\
\hline POLAND & 2.9 & 2 & 8 & -2 \\
\hline PORTUGAL & 1.7 & 2 & 5 & 0 \\
\hline RUSSIA & 1.9 & 2 & 5 & 0 \\
\hline SOUTH AFRICA & -1.5 & -1.5 & 1 & -4 \\
\hline SOUTH KOREA & 2.7 & 3 & 10 & -5 \\
\hline SPAIN & 1.2 & 1 & 6 & -2 \\
\hline SWEDEN & 0.3 & 0 & 1 & 0 \\
\hline TAIWAN & 4.6 & 5 & 5 & 1 \\
\hline THAILAND & 2.0 & 2 & 6 & -8 \\
\hline TURKEY & -4.5 & -4 & 1 & -9 \\
\hline UNITED KINGDOM & 2.3 & 3 & 4 & 0 \\
\hline VENEZUELA & -2.8 & -3 & 0 & -6 \\
\hline
\end{tabular}


Table 4

Determinants of government support of banks

The dependent variable is a ratings-based measure of government support of banks in rating notches (Support), as defined in Section 3. Liabilities / GDP and Assets / GDP are defined as a bank's total liabilities and total assets divided by its homecountry GDP. Log(Assets) is the logarithmic transformation of banks' total assets. Deficit / GDP is the general government's budget deficit expressed as a fraction of GDP. Government ownership is an indicator variable equaling one if the government owns more than $10 \%$ of the cash flow rights of the bank. The specifications in columns 2 and 4 include country and year fixed effects. Standard errors in columns 2 to 4 are clustered by country-year. All specifications are estimated using OLS. ${ }^{* * *}, * *$, and $*$ denote significance at the $1 \%, 5 \%$, and $10 \%$ levels, respectively; $t$-values are shown in italics.

\begin{tabular}{lcccc}
\hline & $(1)$ & $(2)$ & $(3)$ & $(4)$ \\
\hline & & & & \\
Liabilities / GDP & $0.001^{* * *}$ & $0.003^{* *}$ & & $0.008^{* * *}$ \\
Deficit / GDP & 4.201 & 2.014 & & 5.574 \\
& $-0.134^{* * *}$ & -0.047 & -0.047 & -0.067 \\
Assets / GDP & -5.752 & -0.999 & -0.996 & -1.445 \\
Government ownership & & & $0.003^{*}$ & \\
& & & 1.961 & \\
Log (Assets) & & & & -0.142 \\
& & & & -0.517 \\
Liabilities / GDP $x$ Deficit / GDP & & & & -0.333 \\
Constant & & & & -1.053 \\
& & & & $-6.022^{* * *}$ \\
& 0.106 & 0.322 & 0.318 & 3.138 \\
Observations & 0.765 & 0.887 & 0.866 & 0.928 \\
R-squared & & & & \\
\hline Bank fixed effects & 1377 & 1377 & 1377 & 845 \\
Year fixed effects & 0.032 & 0.863 & 0.863 & 0.888 \\
\hline \hline
\end{tabular}


Table 5

Sovereign rating events and country equity indexes

The dependent variable in columns 1 and 2 is the return on country-equity indexes between one day prior and one day after a sovereign event. The dependent variable in columns 3 and 4 is the bank-specific stock returns over the same period. Positive event (Negative event) is defined as the absolute value of a rating or credit outlook change, if this change is positive (negative), and zero otherwise. All specifications include the returns on Datastream's global market index between one day prior and one day after a sovereign event. The specifications in columns 2 and 4 include country and year fixed effects. Regressions are estimated using OLS. ***, **, and * denote significance at the 1\%, 5\%, and $10 \%$ levels, respectively; $t$ values are shown in italics.

\begin{tabular}{lcccc}
\hline & $(1)$ & $(2)$ & $(3)$ & $(4)$ \\
\hline \multirow{4}{*}{ Positive event } & & & & \\
& -0.007 & $-0.008^{*}$ & -0.003 & -0.004 \\
Negative event & -1.618 & -1.745 & -0.550 & -0.745 \\
& $-0.022^{* * *}$ & $-0.021^{* * *}$ & $-0.024^{*}$ & $-0.022^{*}$ \\
& -2.933 & -2.640 & -1.921 & -1.959 \\
& & & & \\
\hline Observations & 223 & 223 & 1,525 & 1,525 \\
R-squared & 0.31 & 0.34 & 0.15 & 0.18 \\
\hline Year fixed effects & No & Yes & No & Yes \\
Country fixed effects & No & Yes & No & Yes \\
Specification & Country & Country & Bank & Bank \\
\hline
\end{tabular}




\section{Table 6}

\section{Sovereign ratings events, government support, and banks’ excess returns}

In columns 1 and 2, the dependent variable is individual banks' excess returns estimated using a market model with the domestic market return used as the market return (“domestic CAPM”). In columns 3 and 4, excess returns are calculated using a global market return ("world CAPM”), a daily stock return measure computed from Datastream's global market index. Excess returns are calculated over the $[-1,1]$ window, relative to the event day. Positive event (Negative event) is defined as the absolute value of a rating or credit outlook change, if this change is positive (negative), and zero otherwise. Support is the numerical difference, in notches, between the foreign currency long-term deposit rating assigned to a bank by Moody's and the bank's financial strength rating (BFSR). Other controls include the lagged log value of banks' market capitalization in U.S. dollars, the lagged log value of the book-to-market ratio, and a measure for the volatility of each bank's stock return. Dummy variables denoting the level of a bank's BFSR prior to the sovereign event are also included as controls, as well as dummy variables for the home-country's sovereign rating prior to the rating event. All specifications include country and year fixed effects, are estimated using weighted least squares, and their standard errors are clustered by country and event. $* * *, * *$, and $*$ denote significance at the $1 \%, 5 \%$, and $10 \%$ levels, respectively; $t$-values are shown in italics.

\begin{tabular}{|c|c|c|c|c|}
\hline & (1) & (2) & (3) & (4) \\
\hline \multirow[t]{2}{*}{ Positive event } & 0.004 & 0.005 & 0.002 & 0.003 \\
\hline & 0.768 & 0.890 & 0.218 & 0.384 \\
\hline \multirow[t]{2}{*}{ Negative event } & -0.002 & 0.001 & -0.008 & -0.003 \\
\hline & -0.393 & 0.165 & -0.825 & -0.375 \\
\hline \multirow[t]{2}{*}{ Support } & & $0.004 *$ & & $0.005^{*}$ \\
\hline & & 1.706 & & 1.788 \\
\hline \multirow[t]{2}{*}{ Positive event $x$ Support } & & -0.002 & & -0.003 \\
\hline & & -1.470 & & -1.305 \\
\hline \multirow[t]{2}{*}{ Negative event $x$ Support } & & $-0.003^{*}$ & & $-0.006^{* * *}$ \\
\hline & & -1.817 & & -2.775 \\
\hline Observations & 1500 & 1500 & 1500 & 1500 \\
\hline R-squared & 0.13 & 0.14 & 0.17 & 0.19 \\
\hline Other controls & Yes & Yes & Yes & Yes \\
\hline Country fixed effects & Yes & Yes & Yes & Yes \\
\hline Year fixed effects & Yes & Yes & Yes & Yes \\
\hline CAPM Model & Domestic & Domestic & World & World \\
\hline
\end{tabular}




\section{Table 7}

\section{Sovereign ratings events, government support, own-sovereign debt holdings, and banks’ excess returns}

In column 1, the dependent variable is individual banks' excess returns estimated using a market model with the domestic market return used as the market return (“domestic CAPM"). In column 2, excess returns are calculated using a global market return ("world CAPM"), a daily stock return measure computed from Datastream's global market index. Excess returns are calculated over the $[-1,1]$ window, relative to the event day. Positive event (Negative event) is defined as the absolute value of a rating or credit outlook change, if this change is positive (negative), and zero otherwise. Support is the numerical difference, in notches, between the foreign currency long-term deposit rating assigned to a bank by Moody's and the bank's financial strength rating (BFSR). Own sovereign debt holdings/T1 is the ratio of net own-sovereign debt holdings to tier 1 capital, as of end-2010, for banks that participated in the 2011 EU-wide stress test coordinated by the European Banking Authority. Other controls include the lagged log value of banks' market capitalization in U.S. dollars, the lagged log value of the book-to-market ratio, and a measure for the volatility of each bank's stock return. Dummy variables denoting the level of a bank's BFSR prior to the sovereign event are also included as controls, as well as dummy variables for the home-country's sovereign rating prior to the rating event. All specifications include country and year fixed effects, are estimated using weighted least squares, and their standard errors are clustered by country and event. ***, **, and $*$ denote significance at the $1 \%, 5 \%$, and $10 \%$ levels, respectively; $t$-values are shown in italics.

\begin{tabular}{lcc}
\hline & $(1)$ & $(2)$ \\
\hline & & \\
Positive event & -0.974 & 0.343 \\
& -0.819 & 0.394 \\
Negative event & 0.010 & 0.038 \\
& 0.200 & 0.917 \\
Support & $0.029^{*}$ & $0.027^{*}$ \\
& 1.851 & 2.016 \\
Positive event $x$ Support & -0.012 & -0.037 \\
& -0.060 & -0.260 \\
Negative event x Support & $-0.024^{*}$ & $-0.019^{*}$ \\
& -1.800 & -1.900 \\
Own-sovereign debt holdings / T1 & 0.000 & 0.000 \\
& -1.717 & -1.606 \\
Positive event $x$ Own-sovereign debt & $0.003^{* *}$ & $0.004^{* * *}$ \\
holdings / T1 capital & 2.929 & 3.464 \\
Negative event $x$ Own-sovereign debt & 0.000 & 0.000 \\
holdings / T1 capital & 1.257 & 0.968 \\
& & \\
\hline Observations & 40 & 40 \\
R-squared & 0.72 & 0.79 \\
\hline Other controls & Yes & Yes \\
Country fixed effects & Yes & Yes \\
Year fixed effects & Yes & Yes \\
CAPM Model & Domestic & World \\
\hline \hline
\end{tabular}




\section{Table 8}

\section{Robustness checks}

In columns 1, the dependent variable is individual banks' excess returns estimated using a market model with the domestic market return used as the market return (“domestic CAPM"). In column 2, excess returns are calculated using a global market return ("world CAPM"), a daily stock return measure computed from Datastream's global market index. In columns 1 and 2 excess returns are calculated over the $[-1,1]$ window, while in columns 3 and 4 are calculated over the $[-5,25]$ window. Positive event (Negative event) is defined as the absolute value of a rating or credit outlook change, if this change is positive (negative), and zero otherwise. In columns 1 and 2, Support is the probability that a bank may receive government support and is calculated as in Gropp, Hakenes, and Schnabel (2011). In columns 3 and 4, Support is the numerical difference, in notches, between the foreign currency long-term deposit rating assigned to a bank by Moody's and the bank's financial strength rating (BFSR). Other controls include the lagged log value of banks' market capitalization in U.S. dollars, the lagged log value of the book-to-market ratio, and a measure for the volatility of each bank's stock return. Dummy variables denoting the level of a bank's BFSR prior to the sovereign event are also included as controls, as well as dummy variables for the home-country's sovereign rating prior to the rating event. All specifications include country and year fixed effects, are estimated using weighted least squares, and their standard errors are clustered by country and event. $* * *, * *$, and $*$ denote significance at the $1 \%, 5 \%$, and $10 \%$ levels, respectively; $t$-values are shown in italics.

\begin{tabular}{|c|c|c|c|c|}
\hline & $(1)$ & $(2)$ & (3) & $(4)$ \\
\hline \multirow[t]{2}{*}{ Positive event } & 0.009 & 0.010 & 0.006 & -0.001 \\
\hline & 1.485 & 1.250 & 0.363 & -0.046 \\
\hline \multirow[t]{2}{*}{ Negative event } & $0.006^{*}$ & 0.007 & $0.022 * *$ & $0.043 *$ \\
\hline & 1.663 & 1.222 & 2.066 & 1.841 \\
\hline \multirow[t]{2}{*}{ Support } & 0.023 & $0.034^{*}$ & -0.001 & 0.003 \\
\hline & 1.614 & 1.746 & -0.112 & 0.334 \\
\hline \multirow[t]{2}{*}{ Positive event $x$ Support } & -0.024 & -0.043 & -0.004 & -0.006 \\
\hline & -1.180 & -1.406 & -1.308 & -1.204 \\
\hline \multirow[t]{2}{*}{ Negative event $x$ Support } & $-0.033^{* * *}$ & $-0.066^{* * *}$ & -0.006 & $-0.022 * *$ \\
\hline & -3.334 & -4.343 & -0.709 & -2.173 \\
\hline Observations & 1500 & 1500 & 1383 & 1383 \\
\hline$R$-squared & 0.14 & 0.20 & 0.12 & 0.18 \\
\hline Other controls & Yes & Yes & Yes & Yes \\
\hline Country dummy & Yes & Yes & Yes & Yes \\
\hline Year dummy & Yes & Yes & Yes & Yes \\
\hline CAPM Model & Domestic & World & Domestic & World \\
\hline Robustness check & \multicolumn{2}{|c|}{$\begin{array}{l}\text { Support defined as a } \\
\text { probability }\end{array}$} & \multicolumn{2}{|c|}{$\begin{array}{c}\text { Excess returns in } \\
{[-5,25] \text { window }}\end{array}$} \\
\hline
\end{tabular}


Table 9

Nonlinear sovereign rating events, government support, and banks' excess returns

In columns 1, the dependent variable is individual banks' excess returns estimated using a market model with the domestic market return used as the market return (“domestic CAPM”). In columns 2, excess returns are calculated using a global market return ("world CAPM"), a daily stock return measure computed from Datastream's global market index. Excess returns are calculated over the $[-1,1]$ window, relative to the event day. Big positive (negative) event is defined as the absolute value of a rating or credit outlook change, if this change is positive (negative) and larger or equal to two, and zero otherwise. Small positive (negative) event is defined as the absolute value of a rating or credit outlook change, if this change is positive (negative) and less than two, and zero otherwise. Support is the numerical difference, in notches, between the foreign currency long-term deposit rating assigned to a bank by Moody's and the bank's financial strength rating (BFSR). Other controls include the lagged log value of banks' market capitalization in U.S. dollars, the lagged log value of the book-to-market ratio, and a measure for the volatility of each bank's stock return. Dummy variables denoting the level of a bank's BFSR prior to the sovereign event are also included as controls, as well as dummy variables for the home-country's sovereign rating prior to the rating event. All specifications include country and year fixed effects, are estimated using weighted least squares, and their standard errors are clustered by country and event. ***, **, and * denote significance at the $1 \%, 5 \%$, and $10 \%$ levels, respectively; $t$-values are shown in italics.

\begin{tabular}{lcc}
\hline & $(1)$ & $(2)$ \\
\hline Big positive event & 0.006 & $-0.029 * *$ \\
Big negative event & 0.673 & -2.290 \\
& 0.003 & 0.001 \\
Small positive event & 0.982 & 0.158 \\
& 0.002 & 0.000 \\
Small negative event & 0.287 & 0.322 \\
& -0.011 & -0.009 \\
Support & -1.231 & -0.736 \\
& $0.004 *$ & 0.005 \\
Big positive event $x$ Support & 1.744 & 1.627 \\
Big negative event $x$ Support & -0.001 & 0.000 \\
Small positive event $x$ Support & -0.835 & 0.260 \\
Small negative event $x$ Support & $-0.004 * * *$ & $-0.010 * * *$ \\
Cour fixed effects & -2.664 & -5.657 \\
CAPM Model & -0.003 & -0.004 \\
R-squared & -1.579 & 0.000 \\
Other controls & -0.004 & -0.004 \\
Country fixed effects & -1.329 & -1.111 \\
& & \\
\hline
\end{tabular}


Table 10

Sovereign ratings events, government support, banks' excess returns, and bank characteristics

The dependent variable is individual banks' excess returns estimated using a global market return (“world CAPM”), a daily stock return measure computed from Datastream's global market index. Excess returns are calculated over the [ -1 , 1] window, relative to the event day. Positive event (Negative event) is defined as the absolute value of a rating or credit outlook change, if this change is positive (negative), and zero otherwise. Support is the numerical difference, in notches, between the foreign currency long-term deposit rating assigned to a bank by Moody's and the bank's financial strength rating. Other controls include the lagged log value of banks' market capitalization in U.S. dollars, the lagged log value of the book-to-market ratio, and a measure for the volatility of each bank's stock return. All specifications include country and year fixed effects, are estimated using weighted least squares, and their standard errors are clustered by country and event. $* * *, * *$, and $*$ denote significance at the $1 \%, 5 \%$, and $10 \%$ levels, respectively; $t$-values are shown in italics.

\begin{tabular}{|c|c|c|c|c|c|c|}
\hline & $(1)$ & $(2)$ & (3) & (4) & (5) & (6) \\
\hline \multirow[t]{2}{*}{ Positive event } & -0.001 & -0.016 & -0.001 & -0.006 & 0.000 & 0.004 \\
\hline & -0.218 & -1.494 & -0.147 & -0.824 & 0.078 & 0.743 \\
\hline \multirow[t]{2}{*}{ Negative event } & -0.002 & $-0.053 * *$ & -0.001 & -0.012 & -0.004 & $0.014 *$ \\
\hline & -0.241 & -2.309 & -0.173 & -0.788 & -0.442 & 1.669 \\
\hline \multirow[t]{2}{*}{ Support } & $0.004 *$ & $0.013^{* *}$ & 0.004 & 0.004 & 0.004 & 0.004 \\
\hline & 1.707 & 2.022 & 1.631 & 1.521 & 1.558 & 1.027 \\
\hline \multirow[t]{2}{*}{ Positive event $x$ Support } & -0.002 & $-0.023^{* * *}$ & -0.002 & -0.002 & -0.002 & 0.003 \\
\hline & -1.215 & -3.168 & -1.136 & -0.912 & -0.985 & 0.986 \\
\hline \multirow[t]{2}{*}{ Negative event $x$ Support } & $-0.006^{* * *}$ & -0.009 & $-0.006^{* * *}$ & $-0.008^{* * *}$ & $-0.006^{* * *}$ & $-0.012 * * *$ \\
\hline & -2.623 & -1.124 & -2.615 & -3.420 & -2.721 & -3.882 \\
\hline \multirow[t]{2}{*}{ Bank characteristic } & $-0.034^{*}$ & $-0.056^{* * *}$ & -0.098 & -0.347 & 0.002 & 0.003 \\
\hline & -1.885 & -2.704 & -0.777 & -1.512 & 0.891 & 1.443 \\
\hline \multirow[t]{2}{*}{ Positive event $x$ Bank characteristic } & & 0.024 & & 0.242 & & -0.001 \\
\hline & & 1.515 & & 0.953 & & -0.855 \\
\hline \multirow[t]{2}{*}{ Negative event $x$ Bank characteristic } & & $0.066^{* *}$ & & 0.415 & & $-0.005^{*}$ \\
\hline & & 2.557 & & 1.216 & & -1.831 \\
\hline \multirow{2}{*}{$\begin{array}{l}\text { Positive event x Support x Bank } \\
\text { characteristic }\end{array}$} & & $0.028 * * *$ & & 0.017 & & $-0.001^{* *}$ \\
\hline & & 3.352 & & 0.379 & & -2.020 \\
\hline \multirow{2}{*}{$\begin{array}{l}\text { Negative event x Support x Bank } \\
\text { characteristic }\end{array}$} & & 0.006 & & $0.149 * * *$ & & $0.002^{*}$ \\
\hline & & 0.544 & & 3.613 & & 1.675 \\
\hline \multirow{2}{*}{$\begin{array}{l}\text { Observations } \\
\text { R-squared }\end{array}$} & 1488 & 1488 & 1453 & 1453 & 1485 & 1485 \\
\hline & 0.18 & 0.20 & 0.18 & 0.19 & 0.18 & 0.19 \\
\hline Other controls & Yes & Yes & Yes & Yes & Yes & Yes \\
\hline Country fixed effects & Yes & Yes & Yes & Yes & Yes & Yes \\
\hline Year fixed effects & Yes & Yes & Yes & Yes & Yes & Yes \\
\hline CAPM Model & World & World & World & World & World & World \\
\hline Bank characteristic & \multicolumn{2}{|c|}{ Deposits / Liabilities } & \multicolumn{2}{|c|}{$\begin{array}{c}\text { Non-interest income / } \\
\text { Assets }\end{array}$} & \multicolumn{2}{|c|}{ BFSR } \\
\hline
\end{tabular}




\section{Table 11}

\section{Sovereign ratings events, government support, and banks’ stock returns - advanced vs. emerging economies}

In columns 1 and 3, the dependent variable is individual banks' excess returns estimated using a market model with the domestic market return used as the market return (“domestic CAPM”). In columns 2 and 4, excess returns are calculated using a global market return ("world CAPM"), a daily stock return measure computed from Datastream's global market index. Excess returns are calculated over the $[-1,1]$ window, relative to the event day. Positive event (Negative event) is defined as the absolute value of a rating or credit outlook change, if this change is positive (negative), and zero otherwise. The specifications in columns 1 and 2 are estimated for the sample of banks in emerging economies, while those in columns 3 and 4 are estimated for the banks headquartered in advanced economies. Support is the numerical difference, in notches, between the foreign currency long-term deposit rating assigned to a bank by Moody's and the bank's financial strength rating (BFSR). Other controls include the lagged log value of banks' market capitalization in U.S. dollars, the lagged log value of the book-to-market ratio, and a measure for the volatility of each bank's stock return. Dummy variables denoting the level of a bank's BFSR prior to the sovereign event are also included as controls, as well as dummy variables for the home-country's sovereign rating prior to the rating event. All specifications include country and year fixed effects, are estimated using weighted least squares, and their standard errors are clustered by country and event. ***, **, and * denote significance at the $1 \%, 5 \%$, and $10 \%$ levels, respectively; $t$-values are shown in italics.

\begin{tabular}{|c|c|c|c|c|}
\hline & (1) & $(2)$ & (3) & $(4)$ \\
\hline \multirow[t]{2}{*}{ Positive event } & 0.006 & 0.003 & -0.017 & -0.003 \\
\hline & 1.010 & 0.348 & -1.568 & -0.244 \\
\hline \multirow[t]{2}{*}{ Negative event } & 0.002 & -0.002 & 0.016 & $0.031^{*}$ \\
\hline & 0.630 & -0.256 & 1.016 & 1.892 \\
\hline \multirow[t]{2}{*}{ Support } & $0.004^{*}$ & 0.006 & -0.002 & -0.001 \\
\hline & 1.680 & 1.634 & -0.702 & -0.171 \\
\hline \multirow[t]{2}{*}{ Positive event $x$ Support } & $-0.002 *$ & -0.003 & 0.002 & 0.000 \\
\hline & -1.723 & -1.382 & 0.658 & -0.057 \\
\hline \multirow[t]{2}{*}{ Negative event $x$ Support } & -0.002 & $-0.006 * *$ & $-0.015^{* *}$ & $-0.018 * *$ \\
\hline & -1.348 & -2.443 & -2.207 & -2.354 \\
\hline Observations & 1045 & 1045 & 455 & 455 \\
\hline$R$-squared & 0.14 & 0.20 & 0.44 & 0.40 \\
\hline Other controls & Yes & Yes & Yes & Yes \\
\hline Country dummy & Yes & Yes & Yes & Yes \\
\hline Year dummy & Yes & Yes & Yes & Yes \\
\hline CAPM Model & Domestic & World & Domestic & World \\
\hline Region & \multicolumn{2}{|c|}{ Emerging Economies } & \multicolumn{2}{|c|}{ Advanced Economies } \\
\hline
\end{tabular}




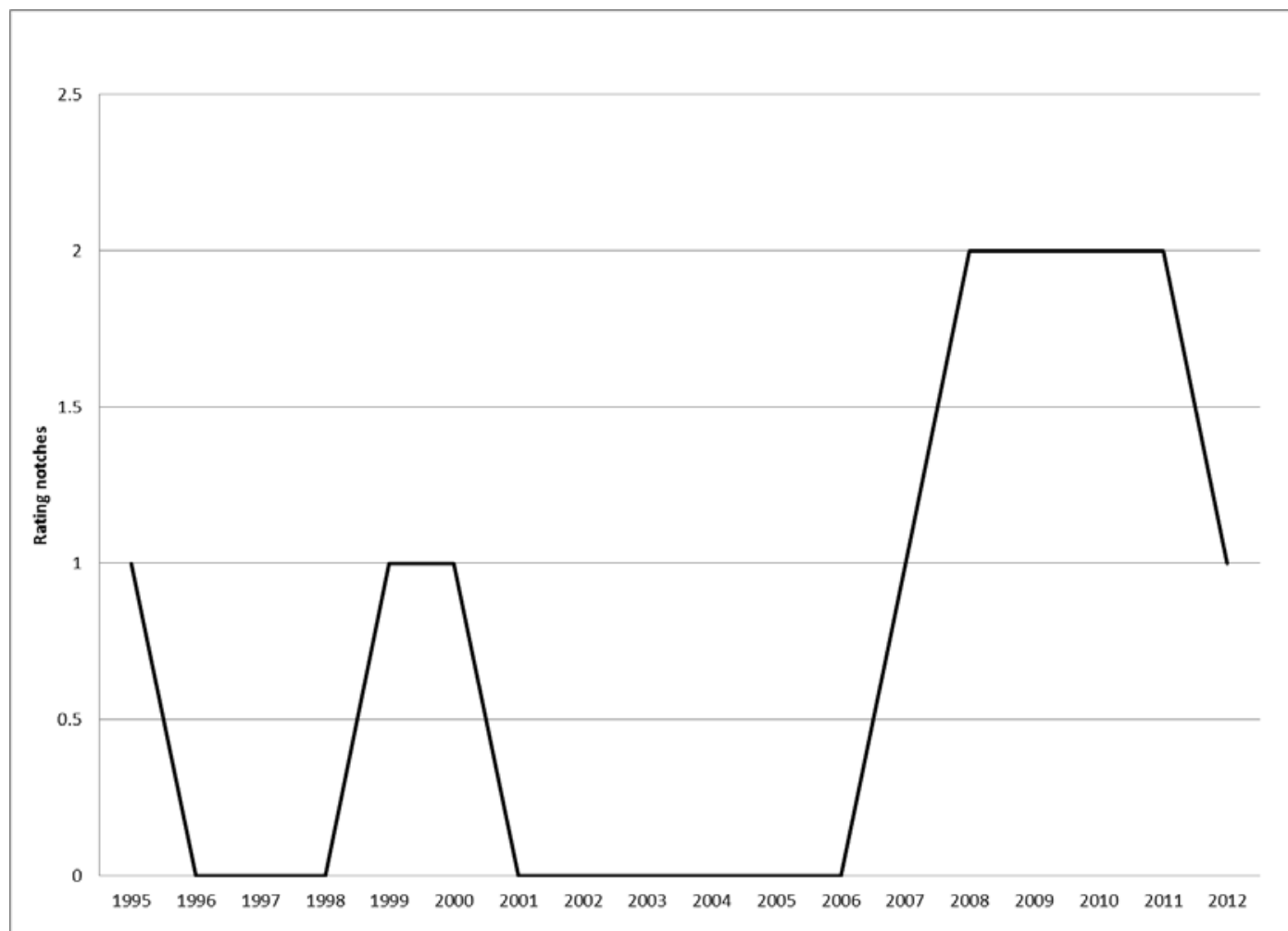

Figure 1. Government support. This figure shows median government support for all banks included in the sample. Support is defined as the difference, in rating notches, between a bank's long term-deposit rating and its standalone rating. 